\title{
TRZY POZIOMY ZAMKNIĘCIA ARGUMENTACJI PRAWNICZEJ
}

\begin{abstract}
Streszczenie. Artykuł przedstawia trzy perspektywy analityczne problemu zamknięcia argumentacji prawniczej na tle centralnych założeń interpretacyjnych dwóch wiodących polskich teorii wykładni, tj. koncepcji klaryfikacyjnej oraz derywacyjnej. Autor prezentuje tezę, że zdolność wykładni operatywnej do regulacji stosunków społecznych jest m.in. wypadkową konkluzywności danego paradygmatu wykładni oraz kontekstu kulturowego, w jakim został osadzony. Niezależnie od uprawomocnienia wyniku interpretacji w dyskursie prawniczym, tj. w środowisku profesjonalistów, możliwa jest sytuacja, gdy dyrektywy wykładni, które stanowią artefakt kulturowy, nie są w pełni kompatybilne z ideologicznymi oraz aksjologicznymi założeniami kultury prawnej i politycznej danego społeczeństwa, stanowiąc niejako kontrproduktywny element tejże kultury.
\end{abstract}

Slowa kluczowe: teoria prawa, argumentacja prawnicza, paradygmat interpretacyjny, konkluzywność wykładni, stosowanie prawa.

\section{THREE LEVELS OF CONCLUSIVENESS OF LEGAL ARGUMENTATION}

\begin{abstract}
Article presents three analytical perspectives of the problem of closing legal argumentation against the background of the central interpretative assumptions of two leading Polish theories of interpretation, i.e. the clarificative and derivational concept. Author presents thesis that the ability of operative interpretation to regulate social relations is, inter alia, the resultant of conclusiveness of a given interpretative paradigm and the cultural context in which it is embedded. Regardless of the validation of the result of interpretation in the legal discourse, i.e. in the environment of professionals, it is possible that the directives of interpretation, which constitute a cultural artifact, are not fully compatible with the ideological and axiological assumptions of the legal and political culture of a given society, constituting a counter-productive element of that culture.
\end{abstract}

Keywords: legal theory, legal argumentation, interpretative paradigm, conclusiveness of interpretation, application of law.

1. Problem granic argumentacji prawniczej dostrzega się na ogół w kontekście ramifikacji sporów interpretacyjnych. W tej optyce na pierwszy plan wysuwa się pytanie, w jaki sposób ma być określony zakres dopuszczalnych argumentów interpretacyjnych, tzn. demarkacja pewnej domeny racji, które mogą być rozpoznane jako ,prawne” (Dyrda, Gizbert-Studnicki 2020, 19-34). Ten kierunek rozważań zwraca w szczególności uwagę na granice prawniczej władzy dyskrecjonalnej nad

\footnotetext{
*Szkoła Główna Handlowa w Warszawie, tgrzyb1@sgh.waw.pl
} 
tekstem, która staje się dyskretną władzą nad prawodawstwem, a w konsekwencji także, do pewnego stopnia, nad społeczeństwem, odsłaniając tym samym problem legitymizacji prawniczych toposów argumentacyjnych. Okazuje się bowiem, że to, co integruje prawników, może wpływać dezintegrująco na rezultaty realizacji prawniczych schematów argumentacyjnych, postrzegane z punktu widzenia zamierzeń prawodawców (polityków), oczekiwań ekonomii, moralności, czy w ogóle społeczeństwa (Bator 2006, 19-21). Napięcie, jakie wytwarza w związku z powyższym stabilizacyjna funkcja kultury prawniczej, prowadzi do zagadnienia uprawomocnienia władzy prawniczej, zwłaszcza gdy przekroczy pożądaną miarę w dążeniu do ujednolicania praktyki prawniczej. Wówczas bowiem to, co wydaje się siłą kultury prawniczej - stałość, staje się jej wadą, eksponując jej konserwatywny charakter i wynikający z tego brak zdolności do szybkiej reakcji na zmiany w rzeczywistości społecznej (Jabłoński, Kaczmarek 2013, 104).

Zagadnienia powyższe można określić jako horyzontalne aspekty legitymizacji argumentacji prawniczej (w płaszczyźnie interpretacyjnej). Ich rewersem jest natomiast wertykalne ujęcie legitymizacji rozumowań prawniczych, tj. zagadnienie konkluzywności (zamknięcia, uprawomocnienia) argumentacji prawniczej. Pojęcie to nie jest jednoznaczne i poddaje się rożnym interpretacjom w zależności od stopnia uniwersalizacji audytorium argumentacji prawniczej, jak też odnośnie poziomu języka. W szczególności możliwe jest rozważanie powyższej kwestii zarówno w ujęciu dogmatycznym, w oparciu o analizę tekstu prawnego, tj. w odniesieniu do funkcjonujących instytucji prawnych bądź de lege ferenda, jak też w perspektywie teoretycznej, tzn. w odniesieniu do meta-języka, tj. języka prawniczego, a zwłaszcza na kanwie wykładni operatywnej. Każdy współczesny system prawny zakłada bowiem jakąś konstrukcję zamknięcia argumentacji (Zirk-Sadowski 1984, 159). Oczywistymi przykładami instytucjonalnych form zakończenia dyskusji toczonej przez uczestników obrotu prawnego są terminy procesowe czy konstrukcja prawomocności orzeczenia. Przedmiotem dalszych rozważań będą natomiast formy uprawomocnienia argumentacji prawniczej relatywizowane do języka prawniczego, a co więcej - do wykładni operatywnej (pominięto zatem np. kwestię konkluzywności sporu co do ustaleń faktycznych). W zależności od stopnia ogólności rozważań, nasuwają się prima facie trzy poziomy teoretycznej analizy zagadnienia zamknięcia dyskursu prawniczego (Grzybowski 2018, $210 \mathrm{i} \mathrm{n.).}$

W pierwszej kolejności można rozpatrywać powyższą problematykę w odniesieniu do rozstrzygnięcia konkretnego przypadku interpretacyjnego, tj. na poziomie jednostkowej decyzji interpretacyjnej. W tym ujęciu, nazwijmy je decyzyjnym, na pierwszy plan wysuwa się kwestia wyczerpania racji interpretacyjnych determinujących rozstrzygnięcie danego przypadku i tym samym uniknięcie swego rodzaju spirali hermeneutycznej. Krótko mówiąc, w pespektywie uzasadniania konkretnej decyzji interesująca jest swego rodzaju ekonomia argumentacji prawniczej. W aspekcie normatywnym wyraża się ona w postulacie redukcji 
kompleksowości, który na gruncie prawoznawstwa przybiera postać reguły interpretacyjnej, zgodnie z którą interpretator (zwłaszcza sąd) nie powinien argumentować za określoną wykładnią przepisów w sytuacji, gdy te nie budzą wątpliwości w sprawie, bowiem taka narracja prowadziłaby „do paraliżu działania instytucji stosujących prawo, które zostałyby zmuszone do marnowania swojego czasu i przytaczania w uzasadnieniach pospolitych komunałów interpretacyjnych" (Morawski 2010, 54).

Drugi poziom analizy tworzy pojęcie dyskursu interpretacyjnego. W tej perspektywie, nazwijmy ją dyskursywną, kwestia zamknięcia argumentacji prawniczej rozpatrywana jest nie tyle na kanwie konkretnego przypadku interpretacyjnego (uzasadnienia decyzji prawnej), co w kontekście możliwości sformułowania efektywnej metody kończenia sporów interpretacyjnych, toczonych w ramach określonej wspólnoty interpretacyjnej, w szczególności w orzecznictwie sądowym. Chodzi tu przede wszystkim o mechanizmy stabilizujące rozumienie tekstów prawnych, czy też utrwalające określone postawy interpretacyjne, tj. w szczególności wskazanie koncepcji wykładni umożliwiającej względnie ugruntowane rozumienie tekstów prawnych przez prawniczą, a zwłaszcza sędziowską wspólnotę interpretacyjną. Owo dyskursywne ujęcie akcentuje więc funkcję petryfikacyjną wykładni prawa, tzn. jej wymiar „precedensowy”, rozumiany jako zdolność utrwalania określonych postaw interpretacyjnych, a tym samym realizacji wartości pewności prawa. Zakłada się tu zatem potrzebę eliminacji potencjalnej nieskończoności argumentacji (regresu ad infinitum) czy jej zapętlenia ${ }^{1}$. Niekiedy rozwiązania takie funkcjonują na poziomie języka prawnego, jak choćby w przypadku uchwał interpretacyjnych sądów najwyższych, innym razem stanowią element kultury prawniczej, jak zasada stare decisis w systemach anglosaskich. $\mathrm{W}$ europejskiej przestrzeni prawnej mamy z nimi jednak do czynienia również za sprawą doktryn interpretacyjnych, takich jak acte éclairé czy acte clair, rozwijanych w orzecznictwie Trybunału Sprawiedliwości Unii Europejskiej, których odpowiednikiem w rodzimym prawoznawstwie jest, zwłaszcza w jej współczesnym ujęciu, koncepcja claritas. Jak bowiem spostrzega Marek Zirk-Sadowski, aktualnie kategorię bezpośredniego rozumienia tekstu prawnego możemy odnosić do sytuacji, gdy nie budzi on wątpliwości z tego powodu, że na przykład został „poprzedzony” linią orzeczniczą czy też uchwałą interpretacyjną (wykładnią legalną). Jeśli znaczenie tekstu prawnego zostaje w taki sposób zbudowane, to ów

\footnotetext{
${ }^{1} \mathrm{Na}$ poziomie filozoficznym zagadnienie to występuje pod postacią pytania o fundamenty naszej wiedzy i jej uzasadnienia. Sceptycyzm wobec możliwości odnalezienia takiego Archimedesowego punktu podparcia wyraża, w szczególności, sformułowany przez Hansa Alberta trylemat Münchhausena, wedle którego każde uzasadnienie prowadzi w ostateczności do dogmatyzmu, regresu w nieskończoność albo też błędnego koła w dedukcji. A ponieważ nie sposób „zgodzić się ani na ciąg nieskończony, ani na błędne koło, przyjęła się tendencja do [...] przerywania procesu uzasadniającego", tj. odwołania się do dogmatu (Albert 1995, 252 i n.).
} 
instytucjonalnie objaśniony tekst traktuje się w kolejnych orzeczeniach jako jasny (Zirk-Sadowski 2012, 157 i n.).

Wreszcie trzecia płaszczyzna odnosi się do wykładni prawniczej postrzeganej jako element komunikacji społecznej, a tym samym do prawa jako wytworu (komponentu) kultury². W tym ujęciu pojęcie zamknięcia interpretacji kładzie nacisk - podobnie jak poziom dyskursu orzeczniczego - na kwestię akceptowalności określonych metod interpretacji tekstów prawnych. Kryterium nie stanowi tu jednak konsensus $\mathrm{w}$ dyskursie prawniczym, $\mathrm{tj}$. pewien stan instytucjonalnej stabilności interpretacji, choć oczywiście nie pozostaje to bez znaczenia. Istotna jest przede wszystkim akceptowalność (względnie podważalność) dyskursu interpretacyjnego w przestrzeni publicznej, tj. jako regulatora stosunków społecznych. Dla tego ujęcia, nazwijmy je politycznym, kluczowa jest warstwa legitymizacyjna prawniczej wykładni prawa, co czyni je zagadnieniem z pogranicza teorii prawa i polityki. Jak bowiem spostrzega William Lucy, racjonalność i legitymizacja to dwie kategorie, do których można sprowadzić cały teoretyczny i aksjologiczny kontekst orzekania. Pierwsza z nich jest bardziej charakterystyczna dla języka teorii prawa, druga dla języka teorii polityki (Lucy 2002, 208-209). Innymi słowy, dla prawnika, jako zaangażowanego uczestnika praktyki, legitymizacja jego działań jest w znacznej mierze oczywista; bardziej interesuje się on uzasadnieniem poszczególnych decyzji, możliwością powiązania ich do innych przesłanek uznanych za dane lub akceptowane przez prawnicze audytorium. $Z$ tego wewnętrznego punktu widzenia ważniejsza jest więc racjonalność i/lub racjonalizacja podejmowanych decyzji. Z kolei dla zewnętrznego (politycznego) obserwatora praktyki prawniczej kwestia prawniczej dyskrecjonalności to przede wszystkim problem legitymizacji władzy. Od prawnika oczekuje się więc odpowiedzi na pytanie: skąd czerpiesz upoważnienie do tego, co robisz? W tej optyce prawnicze wywody pokazujące istnienie elementów kulturowych mogących ściśle zdeterminować praktykę decyzyjną tracą na znaczeniu, zwłaszcza dla teoretyka demokracji i polityki, który myśli w kategoriach władzy oraz suwerenności.

Zatem w zależności od stopnia uniwersalizacji audytorium (Perelman, Olbrechts-Tyteca 1991) ${ }^{3}$ możliwe są różnorodne rozstrzygnięcia odnośnie konstrukcji zamknięcia argumentacji prawniczej. Najbardziej ogólny i zarazem

\footnotetext{
${ }^{2}$ Przykładem koncepcji filozoficzno-prawnej przyjmującej za punkt wyjścia ujęcie prawa jako przedmiotu kulturowego jest egologia Carlosa Cossio (Cossio 2014).

${ }^{3}$ Uczestnicy postępowania, jakkolwiek są najbardziej istotnym audytorium partykularnym, do którego kierowane jest uzasadnienie orzeczenia sądowego, to nie jedynym. W przypadku orzeczeń sądów niższej instancji pisemne ich motywy będą miały, w razie zaskarżenia, zadanie przekonania sądu odwoławczego. Ponadto publikowane orzeczenia podlegać będą ocenie (nieraz krytycznej) środowiska prawniczego (najczęściej przedstawicieli nauki prawa), a wobec tego stanowić będą przedmiot glos i komentarzy. Niejednokrotnie argumentacja podana w uzasadnieniu orzeczenia może przekonać skład orzekający w innej sprawie do zajęcia stanowiska zbieżnego z zaprezentowanym w tym uzasadnieniu. Wreszcie orzeczenia nieraz dotykają kwestii będących przedmiotem debaty publicznej i pozostają w centrum zainteresowania mediów.
} 
niejednoznaczny dla prawnika charakter ma oczywiście perspektywa polityczna, która koncentruje się na społecznym uprawomocnieniu (legitymizacji) praktyki interpretacyjnej, abstrahując od narracji właściwej zaangażowanemu uczestnikowi dyskursu prawniczego, tj. wewnętrznego punktu widzenia (Hart 1998, 143 i n.). Dostrzeżenia wymaga przy tym, że przedstawiona wyżej propozycja metodologiczna ma charakter typologii, tzn. na każdym poziomie refleksji występują swego rodzaju sprzężenia zwrotne. Nie wymaga bowiem szerszego tłumaczenia, że na jednostkową decyzję stosowania prawa przemożny wpływ wywiera przyjmowany warsztat interpretacyjny, a ten z kolei stanowi wypadkową ius interpretandi, które jest składową kultury (prawnej) społeczeństwa. W uzasadnieniu decyzji prawnej ogniskują się zatem nie tylko elementy wewnętrzne, dotyczące jej struktury logicznej, ale też i zewnętrzne, włączając $w$ to założenia filozoficzne interpretatora (Wróblewski 1988, 26). W istocie, wybierając jedno z proponowanych ujęć, nie sposób w pełni zdystansować się od pozostałych płaszczyzn rozważań. Przenikanie się poszczególnych ujęć dogodnie jest przy tym zilustrować na tle dwóch wiodących polskich teorii wykładni: klaryfikacyjnej oraz derywacyjnej.

2. Spośród licznych propozycji teoretycznych koncepcje wykładni klaryfikacyjnej oraz derywacyjnej wywarły największy wpływ na polską naukę prawa, jak też na praktykę prawniczą i jako jedyne rywalizują o miano wiodącej w swojej dyscyplinie. W obecnym stanie dyskusji doktryny te traktowane są raczej jako komplementarne niż konkurencyjne (Zieliński, Zirk-Sadowski 2011, 99-111). Niemniej, mimo że obie teorie opierają się na tym samym pozytywistycznym paradygmacie, trudno uznać, by spór o centralne dla nich meta-zasady wykładni został rozstrzygnięty. Do nich też ograniczymy się w dalszych rozważaniach, tj. do opozycji clara non sunt interpretanda vs. omnia sunt intepretanda.

Pierwsza z ww. zasad, stanowiąca oś teorii klaryfikacyjnej Jerzego Wróblewskiego, zakłada rozróżnienie między „sytuacją interpretacji” a „sytuacją izomorfii”. Ściślej, zasada clara non sunt interpretanda dotyczy drugiego z ww. stanów rzeczy, a podstawową jej funkcją jest wyrażanie idei bezpośredniego rozumienia tekstu prawnego. $Z$ takim stanem rzeczy mamy do czynienia, gdy interpretacja operatywna prawa pozytywnego nie jest konieczna, ponieważ w rozpatrywanej sprawie nie ma uzasadnionych wątpliwości co do znaczenia, w tym zakresu zastosowania normy prawnej (wariant antyinicjujący wykładni). Współcześnie, jak wspomniano, pojmowanie tej dyrektywy wykładni ewoluowało w kierunku traktowania danego tekstu jako jasnego z tego powodu, że posiada on ugruntowaną historię interpretacyjną. Można to odczytywać jako swego rodzaju wersję wariantu antykontynuacyjnego wykładni (Grzybowski 2013, 31-34), a to wobec uznania, że coś, co było interpretacyjnym sufitem, stało się interpretacyjną podłogą i nie wymaga dalszych zabiegów interpretacyjnych (Stelmach 2010, 141-150). Z kolei derywacyjna teoria interpretacji Macieja Zielińskiego ufundowana została na zasadzie omnia sunt interpretanda, która wiąże się z założeniem, że każdy tekst 
prawny może zostać uznany za niejednoznaczny i wobec tego możliwość bezpośredniego rozumienia przepisów jest wykluczona, a wykładnia jest co do zasady konieczna.

Problem powyższy jest uniwersalny z uwagi na jego epistemologiczne w dużej mierze podłoże. Niezależnie od rodzimej dyskusji jego refleksem jego choćby doktryna acte clair, rozwijana w orzecznictwie Trybunału Sprawiedliwości UE (Grabowski 2015, 77). Niemniej, nie jest moją intencją podjęcie kolejnej próby rozstrzygnięcia tej kontrowersji, która zważywszy na jej wielowymiarowość i fundamentalny charakter, wydaje się skazana na niepowodzenie. Spór ów zasadza się bowiem na niezgodzie co do podstawowych presupozycji rozumowania prawniczego i jako taki w ostateczności zdaje się przypominać dylemat wyboru „formy życia" (Wittgenstein 1972, 16), tj. przyjmowanego obrazu interpretacji prawniczej. Nie zamierzam również powielać w tym miejscu rekonstrukcji argumentów podnoszonych w ramach ww. konkurencyjnych zasad wykładni (m.in. Grzybowski 2012). Zwracam natomiast uwagę na przekrojowy charakter obu zasad wykładni w tym znaczeniu, że zależnie od przyjętej optyki odmiennie prezentuje się kwestia zamknięcia argumentacji prawniczej na każdym z trzech ww. poziomów: decyzyjnym, dyskursywnym oraz politycznym.

3. Różnica co do momentu zamknięcia argumentacji prawniczej (interpretacji) jest najbardziej wyraźna w ujęciu decyzyjnym, jako że wskazane wyżej zasady wykładni zgoła odmiennie umiejscawiają koniec dyskusji nad tekstem prawnym. W przypadku ujęcia klaryfikacyjnego, niezależnie od interpretacji historycznej, bądź współczesnej dyrektywy clara non sunt interpretanda, możliwa jest sytuacja, gdy - w szczególności w kontekście uzasadniania, naturalnym dla perspektywy argumentacyjnej (Grzybowski 2012, 52 i n.) - wykładnia w ogóle nie będzie prowadzona, tzn. zostanie a limine wykluczona ze spektrum rozumowania operatywnego. Z kolei w optyce derywacyjnej interpretacja kończy się dopiero w momencie otrzymania

we wszystkich jej aspektach [...] normy zupełnej (mającej zarówno adresata, jak i okoliczności, element nakazu czy zakazu i określenie zachowania się), pełnej co do treści (a więc z uwzględnieniem wszystkich modyfikatorów), wyrażonej w języku ogólnym, zatem powszechnie zrozumiałej i na dodatek jednoznacznej (Zieliński 2010, 254).

Innymi słowy, w klaryfikacyjnym obrazie interpretacji jasność (jednoznaczność) normy może stanowić punkt wyjścia, jako że nawiązuje do sytuacji preinterpretacyjnej, a zatem wykładnia w tym zakresie stanowi przyjęty z góry zespół twierdzeń składających się na uwzględnioną tezę interpretacyjną, tzn. argumentacja nie jest dokonywana, czy też jest zamknięta w tym zakresie niejako in principio. Natomiast w świetle dyrektywy omnia sunt interpretanda norma prawna zawsze stanowi rezultat stosowania sekwencyjnego modelu interpretacyjnego, tzn. kończy się dopiero sformułowaniem tegoż wyrażenia językowego. 
Granica między przedstawionymi tu perspektywami teoretycznymi zaciera się, gdy problem zamknięcia argumentacji prawniczej odnosi się do poziomu dyskursywnego. Na pierwszy plan wysuwa się w tym względzie współczesne rozumienie zasady clara non sunt interpretanda, implikujące twierdzenie deskryptywne, że ,utrwalona praktyka sądowa dotycząca interpretacji przepisów prawnych, zwłaszcza gdy jest ona dość jednoznaczna, wskazuje na treść stosowanego prawa, a więc na wolę ustawodawcy, choćby teoretycznie istniała możliwość innej wykładni” (wyr. TK z 6.09.2001 r., P 3/01, OTK 2001/6/163). W tej perspektywie, określanej też niekiedy instytucjonalną (Zirk-Sadowski 2012, 157), unika się wikłania w zasadnicze spory natury epistemologicznej i etycznej, stawiając na wizję „Wspólnoty interpretacyjnej sędziów”. W prezentowanym ujęciu zamknięcie argumentacji następuje w momencie wypracowania względnie powtarzalnego (utrwalonego) stanowiska w praktyce orzeczniczej, co prowadzi do przeniesienia rozważań na pole tzw. linii orzeczniczych. Brak jest bowiem precyzyjnych kryteriów uznawania danej wykładni za utrwaloną w orzecznictwie. O ile raczej swobodnie można taką cechę orzec o interpretacji wynikającej z uchwały czy orzeczenia prejudycjalnego, o tyle już bardziej złożona jest kwestia ukonstytuowania się określonej linii orzeczniczej czy precedensu interpretacyjnego (tzw. leading case), jako że siła argumentów precedensowych zależy m.in. od trwałości i powtarzalności danego typu rozstrzygnięcia (Grzybowski 2013, 33-34). Istotniejsze jest jednak to, że omawiana tu optyka nie jest niezgodna z założeniami derywacyjnej koncepcji wykładni, skoro w jej świetle „,ktoś, kto dokonał procesu interpretacji i odtworzył normę o określonym sensie, nie musi za każdym razem [...] dokonywać kolejny raz wykładni wysławiającego ją przepisu", a zatem kolejne przypadki rozstrzygnięć „,nie są już w zasadzie przypadkami interpretacyjnymi, lecz po prostu przypadkami decyzyjnymi". W takim stanie rzeczy norma rozumiana jest bowiem „postinterpretacyjnie” (Zieliński 2010, 229, 256-257).

Okazuje się wobec tego, że na poziomie dyskursywnym nie ma różnicy jakościowej pomiędzy obiema konkurencyjnymi koncepcjami wykładni. Ujawnia się ona bowiem nie tyle w zakładanej implicite konstrukcji zamknięcia argumentacji prawniczej, ile w podejściu do nowych argumentów interpretacyjnych. Można bowiem wskazać na swego rodzaju ciążenie teorii klaryfikacyjnej w kierunku tzw. argumentu z orzecznictwa, $\mathrm{tj}$. wzmocnienie roli argumentacji precedensowych w procesie stosowania prawa. Innymi słowy, klaryfikacyjność - przez możliwość wyłączenia sytuacji wykładni a limine - niejako kładzie nacisk na petryfikacyjny rezultat w wykładni prawa, co może prowadzić - zwłaszcza wobec braku wypracowanych doktryn „myślenia precedensowego” na gruncie kontynentalnych systemów prawa (Grzybowski 2015, 147) - do efektu tzw. bezwładności, tj. ujednolicania praktyki prawniczej przez tzw. złe precedensy (Wróblewski 1973, 149). Derywacyjny model wykładni natomiast, poprzez swój holistyczny charakter (Bogucki 2020, 629), niejako zakłada dążenie do sytuacji interpretacyjnej, stąd też nawet ustalenie momentu postinterpretacyjnego stanowi w tym ujęciu 
tylko jeden z argumentów pozwalających na rekonstrukcję normy prawnej. Tym samym różnica między wskazanymi koncepcjami na poziomie dyskursywnym odnosi się $\mathrm{w}$ istocie nie tyle do momentu zamknięcia dyskursu prawniczego, ile do rozkładu ciężaru argumentacji determinującego ustalenia w ww. zakresie. Co do zasady bowiem ujednolicanie praktyki orzeczniczej na podstawie argumentów precedensowych działa imperio rationis, tzn. linie orzecznicze ,ucierają się" na zasadzie wymiany i wzajemnego oddziaływania argumentacji decyzyjnych, a wobec tego sposoby posługiwania się danymi konstrukcjami normatywnymi osiągają rozsądny konsens. $Z$ reguły przekonanie takie wywołuje tzw. ustalona linia orzecznictwa. Wówczas dyrektywa clara non sunt interpretanda przerzuca ciężar obowiązku argumentacyjnego na tego, kto chce wykazać, że mimo wszystko wykładnia powinna być przeprowadzona. Jest ona źródłem roszczenia argumentacyjnego w dyskursie prawnym, stanowiąc jeden $\mathrm{z}$ argumentów w dyskursie, o charakterze niekonkuzywnym (Grzybowski 2013, 35-37). Derywacyjność zakłada natomiast lustrzane odbicie powyższej metody, tzn. roszczenie uzasadnienia sytuacji postinterpretacyjnej, niewymagającej dalszej wykładni, skoro zaleca „dużą ostrożność, bo [...] może powstać potrzeba reinterpretacji danego przepisu" (Zieliński 2010, 229).

Jeszcze inaczej zagadnienie zamknięcia argumentacji przedstawia się w perspektywie społecznej legitymizacji rezultatu wykładni. Wypada w tym względzie zacząć od uwagi, że jakkolwiek już Jerzy Wróblewski wskazywał, że krytyka zasady clara non sunt interpretanda przeprowadzona przez Macieja Zielińskiego wyraża zapatrywania ideologiczne, zamiast opisywać praktykę wykładni prawa (Wróblewski 1987, 64), to dopiero Marek Zirk-Sadowski postawił tezę, że tak rozpatrywany spór o konkurujące meta-dyrektywy wykładni przyjmuje charakter dyskusji o moralności politycznej sędziego i doktrynie podziału władz, a nie z zakresu zwykłej etyki zawodowej. Okazuje się bowiem, że autorytatywność sądowej wykładni prawa może przejawiać się właśnie przez stosowanie zasady omnes sunt interpretanda. Wykładnia może niweczyć działania władzy prawodawczej, gdyż władza sędziowska jest w istocie władzą nad znaczeniem tekstu prawnego (Zirk-Sadowski 2006, 71). Innymi słowy, o ile zasada clara non sunt interpretanda mogła spotkać się z zarzutem ukrywania rzeczywistych motywów rozstrzygnięcia, tj. uchylenia się od uzasadnienia (argumentacji), o tyle zasada omnia sunt interpretanda $\mathrm{z}$ kolei z zarzutem nieuzasadnionego rozszerzania władzy interpretatora poprzez udostępnienie możliwości stosowania różnych metod interpretacji (zwłaszcza pozajęzykowych), których obywatele po prostu nie znają. Oznacza to bowiem, że obywatel może być zaskoczony znaczeniem przepisu prawnego wyprowadzonego przez sąd, który wyklucza stosowanie zasady clara non sunt interpretanda (Grabowski 2015, 82 i n.). Pojawia się więc, w obu wariantach, dobrze znany problem ,przemocy językowej”.

Wskazany punkt widzenia, stanowiąc charakterystyczną dla Marka Zirk-Sadowskiego próbę przekroczenia granicy pomiędzy prawem a nauką, o prawie 
$z$ jednej strony oraz pomiędzy teoretycznym oglądem a ideologią prawa $z$ drugiej, akcentuje w konsekwencji związki wyżej wskazanych zasad interpretacyjnych $\mathrm{z}$ określoną wizją porządku prawnego i politycznego akceptowaną $\mathrm{w}$ przestrzeni publicznej. Tę zależność autor podkreślał też w swych następnych pracach, wywodząc, że „rozumienie prawa i zasada clara non sunt interpretanda jako zakaz inicjatywy interpretacyjnej mogą mieć charakter pozytywnej lub negatywnej oceny komunikacji organów administracji i obywateli w procesie stosowania prawa" (Zirk-Sadowski 2012, 158 i n.). Zdaniem autora jednak, położenie nacisku na językowe aspekty ww. zasady pozwalało stawić umiarkowany opór woluntaryzmowi prawnemu kultury prawnej, na gruncie której została sformułowana (przez rokiem 1989), tj. państwa represyjnego, totalitarnego. Bezpośrednie rozumienie tekstu prawnego stanowiło oręż w nadużywaniu kompetencji przez władze poprzez elastyczne, funkcjonalne stosowanie regulacji prawnych. $Z$ kolei narastająca popularność zasady omnia sunt interpretanda mogła wynikać z rosnącej w demokratycznej Polsce samodzielności sądów w relacji do władzy legislacyjnej. Współcześni sędziowie aktywizują się bowiem jako uczestnicy procesu sprawowania władzy, odrzucając starą formułę ograniczającą ich rolę do bycia „ustami ustawy” (zob. również Grabowski 2015, 84). W tej sytuacji powiązanie zasady omnia sunt interpretanda $\mathrm{z}$ teoriami wykładni opartymi na modelu heurystycznym uzasadnienia decyzji interpretacyjnej może być istotnym czynnikiem zapobiegającym naruszeniu równowagi władz (Zieliński, Zirk-Sadowski 2011, 105).

Zatem na poziomie społecznej legitymizacji argumentacji prawniczej dostrzegalne jest powiązanie zasad clara non sunt interpretanda i omnia sunt interpretanda z określoną wizją kultury prawnej, a w tym względzie miejsca i zakresu władzy sędziowskiej, zwłaszcza w relacji do władzy legislacyjnej. Na poziomie filozoficznym dostrzec można w komentarzach Marka Zirk-Sadowskiego echa znanej metafory ery prawodawców i ery tłumaczy Zygmunta Baumana (szerzej Bauman 1987, passim). W tej optyce doktryna claritas, zwłaszcza w jej pierwotnym, lingwistycznym ujęciu, odpowiadałaby wyborowi „związanego obrazu interpretatora”, który całą odpowiedzialność za treść prawa „ceduje” na prawodawcę. Z kolei otwarcie interpretacyjne sądów zakładane przez zasadę omnes sunt interpretanda powoduje, że przestają być jedynie biernym odtwórcą wizji społeczeństwa narzuconej przez pozostałe władze (zwłaszcza ustawodawczą) i stają się aktywnym aktorem (tłumaczem) życia społecznego. Porzucając rolę „ust ustawy”, sędziowie przyjmują rolę użytkowników struktury instytucjonalnej, od których wymaga się dokonywania wyborów interpretacyjnych, uwzględniających również kontekst pozasystemowy, tj. aktualne warunki społeczne, ekonomiczne, czy polityczne, tak na poziomie państwowym, jak i supranarodowym (Safjan 2010, 108 i n.). Wybór zasady omnes sunt interpretanda oznacza więc wzrost znaczenia roli sędziego, który nota bene generuje problem legitymizacji działań sędziów dostrzegany pod postacią zarzutów o aktywizm sędziowski, prowadzący do „rządów sędziów" (Davis 1987, 559 i n.). 
Na gruncie politycznego (zewnętrznego) ujęcia konkluzywności dyskursu prawniczego różnica w perspektywie obu meta-zasad wykładni zasadza się więc - w przeciwieństwie do dwóch wyżej wymienionych, wewnętrznych ujęć - nie tyle na wskazaniu zakładanego prze nie momentu zamknięcia argumentacji, ile w ich dopuszczalności czy też korespondencji z kulturą prawną i polityczną społeczeństwa. Można na tym tle zaryzykować tezę, że przydatność omawianych zasad interpretacyjnych, a tym samym uwzględnianych modeli zamknięcia argumentacji prawniczej, jest stopniowalna, w zależności od ustroju społecznego. „Języczkiem u wagi" jest we wskazanym zakresie adekwatność względem określonego kontekstu kulturowego, a w tym zwłaszcza wobec założeń konstytuujących społeczne oczekiwania wobec władzy sądowniczej. W zależności od typu kultury prawnej każda z konkurencyjnych dyrektyw może bowiem pełnić funkcję legitymizującą, bądź przeciwnie - delegitymizującą praktykę wykładni. Wydaje się, że roszczenie interpretacyjne związane z zasadą omnia sunt interpretanda jest tym silniejsze, im bliżej responsywnego porządku prawnego, zakładającego kooperację społeczną i negocjacyjny charakter praw i obowiązków oraz wiążący się z nim wzrost znaczenia władzy sądowniczej. Do niedawna dobry przykład mogły stanowić w tym względzie procesy integracyjne w Europie, które w ostatnim czasie uległy pewnemu zahamowaniu. Harmonizacja kultur prawnych, a w szczególności ich podstaw aksjologicznych, dokonywała się bowiem nie tylko na poziomie tekstu prawnego, ale również poprzez dyskurs prawniczy, wyrażający się zwłaszcza w dialogu krajowych i międzynarodowych jurysdykcji sądowych (szerzej Zirk-Sadowski 1997, passim). Natomiast w warunkach prawa autorytarnego zwrot hermeneutyczny, charakterystyczny dla derywacyjnej koncepcji wykładni, może okazać się również kontrproduktywny. Na poziomie praktycznym (techne) hermeneutyka łatwo degeneruje się bowiem do „teorii” manipulacji tekstem, czy raczej toposami dyskursu prawniczego, co czyni wykładnię podatną na nadużycia ze strony interpretatora. W rezultacie zasada omnia sunt interpretanda, która niejako ze swej istoty osłabia konkluzywność procesu wykładni, w warunkach nieresponsywnej kultury prawnej może wręcz osłabiać praktykę interpretacyjną, a przy tym powodować postrzeganie decyzji interpretacyjnych jako podjętych z nadużyciem kompetencji (Kozak 1999, 275, 277).

4. Spostrzeżenia powyższe zdają się ujawniać ważną cechę interpretacji, a mianowicie, że jej zdolność do regulacji stosunków społecznych jest wypadkową m.in. konkluzywności danego paradygmatu wykładni oraz kontekstu kulturowego, w jakim został osadzony. Niezależnie bowiem od uprawomocnienia wyniku wykładni w dyskursie prawniczym, tj. w środowisku profesjonalistów (wewnętrzny punkt widzenia), możliwa jest sytuacja, gdy dyrektywy wykładni, które same stanowią określony artefakt kulturowy, nie są w pełni kompatybilne z ideologicznymi oraz aksjologicznymi założeniami kultury prawnej i politycznej danego społeczeństwa (zewnętrzny punkt widzenia), stanowiąc niejako kontrproduktywny 
element tejże kultury. Innymi słowy, akceptowane w prawniczej wspólnocie interpretacyjnej metody wykładni mogą nie współgrać z oczekiwaniami formułowanymi wobec prawników w przestrzeni publicznej. Dyrektywa interpretacyjna, która stwarza określone możliwości (adaptacyjne, gwarancyjne etc.) w jednym typie kultury prawnej, może mieć szkodliwy wpływ na dyskurs interpretacyjny w innym porządku prawnym, podważając rezultat wykładni i autorytet organu władzy, który się na tę wykładnię powołuje.

\section{BIBLIOGRAFIA}

Albert, Hans. 1995. „Pewność czy prawda?” W Kierunki filozofii wspótczesnej. Cz. I. Red. Józef Pawlak. Tłum. Ija Lazari-Pawłowska. 251-260. Toruń: Wydawnictwo Uniwersytetu Mikołaja Kopernika.

Bator, Andrzej. 2006. „Wspólnota kulturowa jako element integracji prawa”. W Z zagadnień teorii i filozofii prawa. W poszukiwaniu podstaw prawa. Red. Adam Sulikowski. 11-30. Wrocław: Wydawnictwo Uniwersytetu Wrocławskiego.

Bauman, Zygmunt. 1987. Legislators and Interpreters: On Modernity, Post-modernity and Intellectuals. Oxford: Polity Press.

Bogucki, Olgierd. 2020. "The Derivational Theory of Legal Interpretation in Polish Legal Theory". International Journal for the Semiotics of Law - Revue internationale de Sémiotique juridique 33: 617-636.

Cossio, Carlos. 2014. "Phenomenology of the decision". W Latin-American Legal Philosophy. Luis Recasens Siches, Carlos Cossio, Juan Llambias de Azevedo, Eduardo Garcia Maynez. 343-400. Cambridge, Massachusetts: Harvard University Press (reprint).

Davis, Michael Henry. 1987. "A Government By Judges: An Historical Re-View". American Journal of Comparative Law 35: 559-580.

Dyrda, Adam. Tomasz Gizbert-Studnicki. 2020. „Granice sporów interpretacyjnych w prawoznawstwie". Archiwum Filozofii Prawa i Filozofii Społecznej 2: 19-34.

Grabowski, Andrzej. 2015. "Clara non sunt interpretanda vs. omnia sunt interpretanda: Aneverending controversy in Polish legal theory?". Revus - Journal for Constitutional Theory and Philosophy of Law 27: 67-97.

Grzybowski, Tomasz. 2012. „Spory wokół zasady clara non sunt interpretanda”. Państwo i Prawo 9: $44-56$.

Grzybowski, Tomasz. 2013. „Jednolitość orzecznictwa a paradygmat interpretacyjny (ze szczególnym uwzględnieniem reguły clara non sunt interpretanda)". Archiwum Filozofii Prawa i Filozofii Społecznej 2: 25-37.

Grzybowski, Tomasz. 2015. „Interpretacyjny park jurajski: odpowiedź Agnieszce Choduń”. Archiwum Filozofii Prawa i Filozofii Społecznej 2: 142-148.

Grzybowski, Tomasz. 2018. "Effectiveness of interpretation in the context of Polish theories of legal interpretation". W Mind the Gaps. Economical Aspects in the Legal Thinking. Red. Tomasz Bekrycht, Sergiy Glibko, Bartosz Wojciechowski. 209-221. Łódź: Wydawnictwo Uniwersytetu Łódzkiego.

Hart, Herbert L.A. 1998. Pojęcie prawa. Warszawa: Wydawnictwo Naukowe PWN.

Jabłoński, Paweł. Przemysław Kaczmarek. 2013. „O trzech granicach władzy prawniczej”. Archiwum Filozofii Prawa i Filozofii Społecznej 1: 93-108. 
Kozak, Artur. 1999. „Prawoznawstwo pomiędzy techne a episteme. Uwagi w związku z pracą M. Zirk-Sadowskiego Prawo a uczestniczenie w kulturze". Ruch Prawniczy, Ekonomiczny i Socjologiczny 3-4: 269-278.

Lucy, William. 2002. "Adjudication". W The Oxford Handbook of Jurisprudence and Philosophy of Law. Red. Jules L. Coleman, Kenneth E. Himma, Scott J. Shapiro. 206-267. Oxford: Oxford University Press.

Morawski, Lech. 2010. Zasady wyktadni prawa. Toruń: TNOiK - Towarzystwo Naukowe Organizacji i Kierowania. „Dom Organizatora”.

Nonet, Phillipe. Philip Selznick. 1978. Law and Society in Transition. Towards Responsive Law. New York: Harper Colophon Books.

Perelman, Chaim. Lucie Olbrechts-Tyteca. 1991. The New Rhetoric: A Treatise on Argumentation. Notre Dame: University of Notre Dame Press.

Safjan, Marek. 2010. "The Universalisation of Legal Interpretation". W Interpretation of Law in the Global World: From Particularism to a Universal Approach. Red. Joanna Jemielniak, Przemysław Miklasiewicz. 107-124. Berlin-Heidelberg: Springer.

Stelmach, Jerzy. 2010. „Przypadek trudny w prawie”. W W poszukiwaniu dobra wspólnego. Ksiegga jubileuszowa Profesora Macieja Zielińskiego. Red. Agnieszka Choduń, Stanisław Czepita. 141-150, Szczecin: Wydawnictwo Uniwersytetu Szczecińskiego.

Wittgenstein, Ludwig. 1972. Dociekania filozoficzne. Tłum. B. Wolniewicz. Warszawa: Państwowe Wydawnictwo Naukowe.

Wróblewski, Jerzy. 1973. Wartości a decyzja sq̨dowa. Wrocław: Zakład Narodowy im. Ossolińskich.

Wróblewski, Jerzy. 1987. "An outline of a general theory of legal interpretation and constitutional interpretation”. Acta Universitatis Lodziensis. Folia Iuridica 32: 33-89.

Wróblewski, Jerzy. 1988. „Poziomy uzasadnienia decyzji prawnej”. Studia Prawno-Ekonomiczne XL: 17-33.

Zieliński, Maciej. 2010. Wyktadnia prawa. Zasady, reguły, wskazówki. Warszawa: LexisNexis.

Zieliński, Maciej. Marek Zirk-Sadowski. 2011. „Klaryfikacyjność i derywacyjność w integrowaniu polskich teorii wykładni prawa”. Ruch Prawniczy, Ekonomiczny i Socjologiczny 2: 99-111.

Zirk-Sadowski, Marek. 1984. Rozumienie ocen w języku prawnym. Łódź: Wydawnictwo Uniwersytetu Łódzkiego.

Zirk-Sadowski, Marek. 1997. "Institutional and Cultural Dimensions of Legal Interpretation". Studia Prawno-Europejskie 2: 7-18.

Zirk-Sadowski, Marek. 2006. „Epistemologia prawa a teorie wykładni”. W Prawo - Władza - Społeczeństwo - Polityka. Księga Jubileuszowa Profesora Krzysztofa Paleckiego. Red. Maria Borucka-Arctowa. 67-78. Toruń: Wydawnictwo Adam Marszałek.

Zirk-Sadowski, Marek. 2012. „Pojęcie, koncepcje i przebieg wykładni prawa administracyjnego”. W System prawa administracyjnego. Red. Roman Hauser, Zygmunt Niewiadomski, Andrzej Wróbel. T. 4. Wyktadnia w prawie administracyjnym. 131-188. Warszawa: C.H. Beck.

\section{Orzecznictwo}

Wyrok TK z 6.09.2001 r., P 3/01, OTK 2001/6/163. 